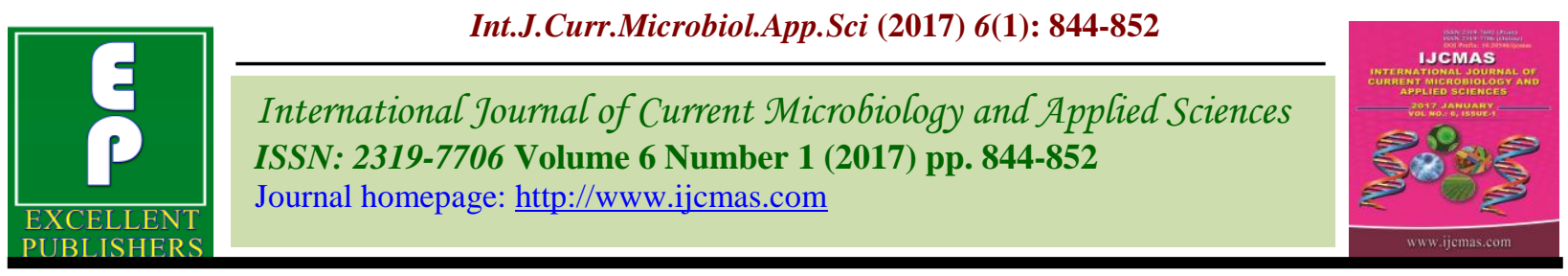

Review Article

http://dx.doi.org/10.20546/ijcmas.2017.601.099

\title{
Phosphate Solubilizing Microbes: An Overview
}

\author{
Krishnananda Pralhad Ingle ${ }^{1 *}$ and Dipika Ashokrao Padole ${ }^{2}$
}

Biotechnology Centre, Dr. Panjabrao Deshmukh Krishi Vidyapeeth, Akola, Maharashtra, India

*Corresponding author

A B S T R A C T

\section{Keywords}

Phosphate solubalizing microorganisms (PSM), Plant growth promoters (PGPR), Mechanism of $\mathrm{P}$ solubilization,

\section{Article Info}

Accepted: 28 December 2016 Available Online: 10 January 2017
Phosphorous is one of the most abundant metallic element found in the earth's crust and present in soils in both organic and inorganic forms. Though it is present in high concentration, only $0.1 \%$ of the total $\mathrm{P}$ is available to plant because of poor solubility and its fixation in soil with other metallic elements in the soil such as $\mathrm{Ca}, \mathrm{Al}, \mathrm{Fe}$ to form calcium phosphate, aluminum phosphate and ferrous phosphate and thus becomes unavailable to plants. Tremendous application of chemical based P fertilizers has long term impact on the environment in terms of eutrophication, soil fertility depletion, carbon footprint this attitude compelled us to find a sustainable approach for efficient $\mathrm{P}$ availability in agriculture to meet the over growing demand of food. The use of efficient PSM (phosphate-solubilizing microorganisms), opens up a new horizon for better crop productivity and for greater yield performance without affecting the soil health. Phosphate solubilizing microorganism plays an important role in the plant nutrition through increase in P uptake by the plants and their use as PGPR is an important contribution to biofertilization of agricultural crops. Though some of the bacterial strain such as (Pseudomonads and bacilli) and fungal strains (Aspergillus and Penicillium) have been identified as PSM their relative performance under in situ conditions is not reliable and therefore there is a need of genetically modified strains which could lead better $\mathrm{P}$ solubilizition and improve the plant health. The present review mostly focuses on the phosphate plant interaction, PSM, mechanism of P solubilization, PSM as plant growth promoter and genetic manipulation of several genes involved in mineral and phosphate $\mathrm{P}$ solubilization.

\section{Introduction}

To meet the demand of overgrowing population it is the need of agrarian community to enhance the yield and future food supply. To overcome these problems, efforts needed to focus the soil biological system and the agro-ecosystem for better understanding the complex processes and their interactions for governing the stability of agricultural land.
The green revolution has been proved the most intellectual human activities contributing global food security and, consequently, changes the face of developing countries, such as India, from being fooddeficient to having a food surplus. In present conditions there is an urgent need of second green revolution to increase the food production by around $50 \%$ in coming next 20 
years to fulfill the demand of increasing population pressure (Vasil, 1998; Leisinger, 1999).

Chemical fertilizers, such as water-soluble phosphatic (WSP) fertilizers have played a significant role in the green revolution to rectify the phosphorus deficiencies. However, excessive use of chemical pesticides arises soil health issues and beyond certain limit the yield plateau get declined (Ahmed, 1995). Thus it becomes clear that conventional agricultural practices cannot sustain the production base, for too long; while, to augment crop productivity agronomists have to rely on chemical fertilizers. In this context, after nitrogen, phosphorus is an essential plant nutrient whose deficiency marked the high yield. The phosphorous is present only in micro molar or lesser quantities in the earth's crust (Ozanne, 1980) and is highly reactive with other elements in the soil.

Phosphorous is a one of the most abundant metallic elements found in the earth's crust and is present in the soils in both inorganic and organic forms (Gyaneshwar et al., 2002). It is utilized or absorbed by the plants in inorganic form i.e. in orthophosphate $\left(\mathrm{H}_{2} \mathrm{PO}^{4-}\right.$ and $\mathrm{HPO}_{4}{ }^{2-}$ ) (Hinsinger, 2001). It has a key role in metabolic processes such as photosynthesis, energy transfer, signal transduction, nitrogen fixation in legumes, crop quality and resistance to plant diseases are the main features associated with phosphorous nutrition (Sperber, 1958a; Khan et al, 2014).

Phosphorus being a structural component of many coenzymes, phospho-proteins, phospholipids (Ozane et al., 1980) also forms a part of the genetic memory "DNA" of all living organisms. It involved in transfer and storage of energy which used for growth and reproduction. Phosphorus plays a lead role in especially in photosynthesis, carbon metabolism, and membrane formation (Wu, 2005) also the vital role in elongation of root, proliferation, and phosphorous deficiency affects root architecture (Borch et al., 1999; Williamson et al., 2001). A major portion of phosphorus absorbed by the plant is accumulated in grain in the form of phytic acid which becomes unavailable to plants and its deficiency negatively affects grains yield (Richardson, 1994).

Tropical and subtropical regime has acidic soil considered as extremely deficient in phosphorus with high phosphorus sorption (fixation) capacities. On average, most mineral nutrients in soil solution are present in millimolar amounts but phosphorus is present only in micromolar or lesser quantities (Ozanne, 1980). The low levels of phosphorus are due to high reactivity of soluble phosphate with other elements.

A number of heterotrophic microorganisms excreting organic acids which solubalized $\mathrm{P}$ that chelate cationic partners of $\mathrm{P}$ ions and release the $\mathrm{P}$ directly into solution (He et al., 2002). These phosphate solubilizing bacteria (PSB) are being used as biofertilizer since 1950s. Microbial inoculants assimilate soluble $\mathrm{P}$, and prevents it from adsorption or fixation (Khan and Joergesen, 2009). These microorganisms influences soil fertility through various processes viz. decomposition, mineralization and release of nutrients. Microorganisms enhance the $\mathrm{P}$ availability to plants through solubilization of inorganic form of $\mathrm{P}$ to in available form (Chen et al., 2006; Kang et al., 2002). Hence, microbial inoculants are used as an alternate source, which are both economic as well as ecofriendly. A continued exploration of the natural biodiversity of soil microorganisms and the optimization of microbial interactions in the rhizosphere represents a prerequisite step to develop the more efficient microbial inoculants with phosphorus-solubilizing ability. 


\section{Phosphate -Plant Interaction}

Phosphorus is one the major nutrient limiting plant growth. It has diverse role in plant nutrition and promotes the development of deeper roots. The soil that is rich in phosphorus constitutes about $0.05 \%(\mathrm{w} / \mathrm{w}$ ) phosphorus but only one tenth of this is available to plants. Most of the P (95-99\%) present in the soil in the insoluble form and hence cannot be utilized by the plants due to chemical fixation in the soil and it's interaction with other metallic elements that are present in the rhizospheric area (Gaur and Gaind, 1999). To increase the availability of phosphorus for plants, large amounts of fertilizer is used on a regular basis. But the continuous application of fertilizer $\mathrm{P}$ is rapidly transferred to the insoluble forms (Abd Alla, 1994) and thus there is a need of phosphate solubilizing microorganism to make the $\mathrm{P}$ in available form to the plants.

\section{Phosphate Solubilizing Micro-Organisms}

Naturally occurring rhizospheric phosphorus solubilizing microorganism (PSM) dates back to 1903 (Khan et al., 2009). Number of microbial species plays key role in $\mathrm{P}$ solubilization these includes bacteria, fungi, actinomycetes and even algae. Bacteria are predominant amongst them and proved more effective in phosphorus solubilization than fungi. In addition to Pseudomonas and Bacillus, other bacteria reported as Psolubilizers these are Rhodococcus, Arthrobacter, Serratia, Chryseobacterium, Phyllobacterium etc. (Wani et al. 2005), Azotobacter (Kumar et al. 2001), Xanthomonas (De Freitas et al. 1997), Enterobacter, Pantoea, and Klebsiella (Chung et al. 2005). Several halophilic bacteria Kushneria sinocarni have also been isolated from the sediment of Daqiao saltern on the eastern coast of China, which may be useful in stress conditions; salt affected agricultural soils (Zhu et al. 2011). Among the whole microbial population in soil, PSB constitute 1 to $50 \%$, while phosphorus solubilizing fungi (PSF) are only 0.1 to $0.5 \%$ in $\mathrm{P}$ solubilization potential (Chen et al., 2006) which includes Penicillium and Aspergillus, Rhizoctonia solani, Trichoderma.

Moreover, fungi in soils are able to traverse long distances more easily than bacteria and hence, may be more important to $\mathrm{P}$ solubilization in soils (Kucey 1983). Generally, the P-solubilizing fungi produce more acids compared to bacteria and thus leads more P-solubilizing activity (Venkateswarlu et al. 1984). Among the yeasts, Yarrowia lipolytica has potential to solubilize phosphate. Algae such as cyanobacteria and mycorrhiza have been also reported for P solubilization activity. A partial list of PSM including various groups is given in Table 1.

\section{Mechanism of Phosphate Solubilization}

The mechanism of $\mathrm{P}$ solubilization that is employed mostly by soil microorganisms includes: (1) release of complex compounds e.g. organic acid anions, siderophores, protons, hydroxyl ions, $\mathrm{CO} 2$, (2) liberation of extracellular enzymes or it also referred as biochemical $\mathrm{P}$ mineralization and (3) the release of $\mathrm{P}$ during the degradation of substrate (McGill and Cole 1981). Thus, microorganisms have key role in the soil $\mathrm{P}$ cycle i.e. precipitation, sorption-desorption, and mineralization.

\section{Inorganic phosphate solubilization}

Microorganism plays an important role in $\mathrm{P}$ solubilization through secretion of organic acid production either by: (i) lowering the $\mathrm{pH}$, or (ii) through chelation reaction of cations bound to $\mathrm{P}$ (iii) by competing with $\mathrm{P}$ for adsorption sites on the soil. 
The lowering in $\mathrm{pH}$ of the medium suggests the secretion of organic acids by the Psolubilizing microorganisms (Whitelaw 2000; Maliha et al. 2004) via direct oxidation pathway that occurs on the outer face of the cytoplasmic membrane (Zaidi et al. 2009). When $\mathrm{P}$ is applied to soil it get interact with other metallic elements such as $\mathrm{Fe}, \mathrm{Al}$ and $\mathrm{Ca}$ ions which makes the $\mathrm{P}$ unavailable to plants through the formation of ferrous phosphate, aluminium phosphate, calcium phosphate etc. and the release of organic acids by PSM leads the chelation reaction and because of this the bound $\mathrm{P}$ to other metallic elements get freed and becomes available to plants. The prominent acids that are released by PSM in the solubilization of insoluble $\mathrm{P}$ are gluconic acid, oxalic acid, citric acid (Kim et al. 1997), lactic acid, tartaric acid and aspartic acid etc. (Venkateswarlu et al. 1984).

The another mechanism is the production of $\mathrm{H}_{2} \mathrm{~S}$, which react with ferric phosphate to yield ferrous sulphate with the release of phosphate (Swaby and Sperber 1958). It could be because of the activity of PSM occurs as a consequence of microbial sulphur oxidation (Rudolph 1922), nitrate production and CO2 formation. These processes ultimately leads the formation of inorganic acids like sulphuric acid (Sperber 1958 a).

\section{Organic Phosphate Solubilization}

Phosphorus can be released in the soil from organic compounds by three groups of enzymes: (1) Nonspecific phosphatases, which leads dephosphorylation of phosphoester or phosphoanhydride bonds in organic matter, (2) Phytases, which mostly release P which is intact in the form of phytic acid, and (3) Phosphonatases and C-P Lyases, the phosphonates degrading enzyme enzymes that perform $\mathrm{C}-\mathrm{P}$ cleavage in organophosphonates. Availability of organic phosphate compounds for plant nutrition could be a limitation because as phosphorous is highly reactive it will interact with other metallic elements that are present in the soil in the rhizospheric area and becomes unavailable to plants which retard the plant growth and subsequently crop yield. Therefore, the capability of enzymes to perform the desired function in the rhizosphere is a crucial aspect for their effectiveness in plant nutrition (Tarafdar and Jungk, 1987; Tarafdar and Claassen, 1988).

\section{Role of Microbial Exopolysaccharides in Phosphate Solubilization}

Recently the role of polysaccharides in the microbial mediated solubilization of $\mathrm{P}$ was assessed by $\mathrm{Yi}$ et al. (2008). Microbial exopolysaccharides (EPSs) are polymers that mainly consist of carbohydrates excreted by some bacteria and fungi onto the outside of their cell walls. Bacterial strains such as Enterobacter sp. (EnHy-401), Arthrobacter sp. (ArHy-505), Azotobacter sp. (AzHy-510) and Enterobacter sp. (EnHy-402), has the ability to solubilize TCP (tri calcium phosphate).

\section{Phosphate Solubilizing Bacteria as Plant Growth Promoters}

There are several reports on plant growth promotion by bacteria that have the ability of solubilize inorganic and/or organic $\mathrm{P}$ from soil after their inoculation in soil or plant seeds (Kloepper et al., 1988; Gaur and Ostwal, 1972; Subba Rao, 1982; Gerretsen, 1948; Cooper, 1959). It was reported that a strain of Burkholderia cepacia, commercially used as biofertilizer in Cuba which display significant mineral phosphate solubilization and moderate phosphatase activity, also improve the yield of tomato, potato, onion, banana, coffee etc. (Chabot et al., 1993). Inoculation with two strains of Rhizobium leguminosarum selected for their $\mathrm{P}$ solubilization ability has been shown to 
improve root colonization and growth promotion and to increase significantly the $\mathrm{P}$ concentration in lettuce and maize (Chabot 1996a). Also a strain of Pseudomonas putida stimulate the growth of roots and shoots and increased ${ }^{32} \mathrm{P}$-labeled phosphate uptake in canola (Lifshitz et al, 1987). Co-inoculation of Pseudomonas striata and Bacillus polymyxa strains showing phosphate solubalizing activity, with a strain of Azospirillium brasilense, resulted in significant increase in grain and dry matter yields, with a concomitant increase in $\mathrm{N}$ and $\mathrm{P}$ uptake (Alagawadi et al., 1992). Several studies have shown that PSB interacts with the vesicular arbuscular mycorrhizae (VAM) by releasing phosphate ions in the soil, which causes synergistic interaction that allows for better exploitation of poorly soluble $\mathrm{P}$ sources (Ray et al., 1981). Phylazonit-M is the commercial biofertilizer which contains the mixtures of different bacterial cultures such as Bacillus megaterium, Azotobacter chroococcum increases $\mathrm{N}$ and $\mathrm{P}$ supply to the plants (permission at No. 9961, 1992, by the Ministry of Agriculture of Hungary) similarly, other product named "KYUSEI EM", a mixed inoculums of lactic acid bacteria, the organic acid lactic acid being the agent for the mineral phosphate solubilization.

\section{Genetic Engineering of Phosphate Solubilizing Microorganisms}

Some of the genes have been reported involved in mineral and organic phosphate solubilization has been so far isolated and characterized (Rodriguez et al. 2006). Genetic manipulation of these genes followed by their expression in selected rhizobacterial strains leads a promising perspective for obtaining PSM strains with higher phosphate solubilizing capacity, and thus it become more effective as agricultural inoculants. The initial achievement was achieved by Goldstein and Liu (1987) from the Gram negative bacteria Erwinia herbicola through cloning of $\mathrm{P}$ solubilization genes. Similarly, the napA phosphatase gene from the soil bacterium Morganella morganii was transferred to Burkholderia cepacia IS-16, a strain used as a biofertilizer, using the broadhost range vector pRK293 (Fraga et al., 2001). Introduction of $P$ solubilization genes in natural rhizosphere bacteria is a candidate approach for the improvement of microbial capacity.

Fourteen different nonspecific acid phosphatase encoding genes have been isolated from different bacterial species using different expression cloning system (Rossoloni et al., 1984). Sequence analysis of the cloned phosphatase genes allowed the classification into three different families: class A, class B, and class $\mathrm{C}$ phos- phatases (Thaller et al., 1994; Thaller et al., 1995a; Thaller et al., 1997). Several other phosphatase genes have been isolated from Escherichia coli. These include: ushA, which encodes a 5'-nucleotidase (Burns et al., 1986); agp, which encodes an acid glucose-1phosphatase (Pradel et al., 1990) and cpdB, encoding the 2'-3' cyclic phosphodiesterase (Beacham et al., 1980). Despite the diffculties, significant progress has been made for obtaining genetically engineered microorganisms for the agricultural use (Armarger 2002).

In conclusion, phosphorus is an essential element in crop nutrition. Continuous application of chemical based $\mathrm{P}$ fertilizers compelled us to find a sustainable approach for efficient $\mathrm{P}$ availability in agriculture to meet the over growing demand of food. Soil microorganisms plays varied role that affect the transformation of $\mathrm{P}$ and thus influence the availability of $\mathrm{P}$ to plant roots. 
Int.J.Curr.Microbiol.App.Sci (2017) 6(1): 844-852

Table.1 Biodiversity of P Solubilizing Microorganisms

\begin{tabular}{|ll|}
\hline Groups & Examples \\
\hline $\mathbf{N}_{2}$ fixing biofertilizers & \\
Free living & Azotobacter, Beijerinkia, Clostridium, Klebsiella, Anabaena and Nostoc \\
Symbiotic & Rhizobium, Frankia and Anabaena azollae \\
Associative symbiotic & Azospirillum \\
P solubilising biofertilizers & \\
Bacteria & Bacillus megaterium var. phosphaticum, Bacillus subtilis, Bacillus circulans and Pseudomonas striata \\
Fungi & Penicillium sp. and Aspergillus awamori \\
P mobilizing biofertilizers & \\
Arboscular mycorhiza & Glomus sp., Gigaspora sp., Acaulospora sp., Scutellospora sp. and Sclerocystis sp. \\
Ectomycorrhiza & Laccaria sp., Pisolithus sp., Boletus sp. and Amanita sp. \\
Ericoidmycorrhiza & Pezizella \\
Orchid mycorrhiza & Rhizoctonia solani \\
Biofertilizers for micro nutrients & \\
Silicate and Zinc solubilizers & Bacillus sp. \\
Plant growth promoting rhizobacteria & Pseudomonas fluorescens \\
\hline \begin{tabular}{l} 
Pseudomonas \\
\hline
\end{tabular}
\end{tabular}

The use of efficient PSM (phosphatesolubilizing microorganisms), opens up a new horizon for better crop productivity and for greater yield performance without affecting the soil health. Phosphate solubilizing bacteria play an important role in the plant nutrition through increase in $\mathrm{P}$ uptake by the plants and their use as PGPR is an important contribution to biofertilization of agricultural crops. Therefore, steps should be taken for extensive and consistent research for the identification and characterization of PSM with greater efficiency for their ultimate application under field conditions. It becomes the responsibility of soil scientists and microbiologists how soil $\mathrm{P}$ could be improved without applying the chemical based phosphatic fertilizers under different agroclimatic regions.

Genetic engineering of the phosphate solubilizing character must eventually be directed to the chromosomal integration of the gene for higher stability of the character and to avoid horizontal transfer of the inserted gene in soil. This strategy would also prevent the risk of metabolic load caused by the presence of the plasmid in the bacterial cell.
Thus the exploitation of the candidate soil microorganisms which play an important role in the mobilization of soil $\mathrm{P}$ and understanding the mechanism of phosphate solubilization, phosphate plant interaction and their contribution to the cycling of $\mathrm{P}$ in soilplant systems is essential for the development of sustainable agriculture to forward and accomplished our movement from a green revolution to an evergreen revolution.

\section{References}

Abd-Alla, M.H., 1994. Phosphatases and the utilization of organic phosphorus by Rhizobium leguminosarum biovar viceae. Lett. Appl. Microbiol. 18: 294-296. Barber, S.A., 1984. Soil Nutrient Bioavailability: AMechanistic Approach. John Wiley, New York

Ahmed S. 1995. Agriculture - Fertilizer Interface In Asia Issues of Growth and sustainability, Oxford and IBH publishing Co, NewDelhi.

Alagawadi AR, Gaur AC. 1992. Inoculation of Azospirillum brasilense and phosphatesolubilizing bacteria on yield of sorghum [Sorghum bicolor (L.) Moench] in dry land. Trop Agric;69:347-50. 
Armarger N 2002. Genetically modified bacteria in agriculture. Biochimie 84:1061-1072

Beacham IR, Garrett S. 1980. Isolation of Escherichia colimutants (cpdB) deficient in periplasmic 2 -cyclic phosphodiesterase and genetic mapping of the cpdB locus. J Gen Microbiol; 119:31-34.

Borch K, Bouma TJ, Lynch, Brown KM. 1999. Ethylene: a regulator of root architectural responses to soil phosphorus availability. Plant Cell Environ;22:425-31.

Burns DM, Beacham IR. 1986. Nucleotide sequence and transcriptional analysis of the Escherichia coli ushAgene, encoding periplasmic UDP-sugar hydrolase (5'nucleotidase): regulation of the ushA gene, and thesignal sequence of its encoded protein product. Nucleic Acids Res; $14: 4325-42$.

Chabot R, Antoun H, Cescas MP. 1993. Stimulation de la croissance du mais et de la laitue romaine par desmicroorganismes dissolvant le phosphore inorganique. Can J Microbiol;39:941-7.

Chabot R, Antoun H, Kloepper JW, Beauchamp CJ. 1996a. Root colonization of maize and lettuce by bioluminis-cent Rhizobium leguminosarum biovar. phaseoli. Appl Environ Microbiol;62:2767-72.

Chabot R, Hani A, Cescas PM. 1996b. Growth promotion of maize and lettuce by phosphate-solubilizing Rhizo- bium leguminosarumc biovar. phaseoli. Plant Soil;184:311-21.

Chen YP, Rekha PD, Arun AB, Shen FT, Lai WA, Young CC. 2006. Phosphate solubilizing bacteria from subtropical soil and their tricalcium phosphate solubilizing abilities. Appl Soil Ecol 34:33-41

Chung H, Park M, Madhaiyan M, Seshadri S, Song J, Cho H, Sa T. 2005. Isolation and characterization of phosphate solubilizing bacteria from the rhizosphere of crop plants of Korea. Soil Biol Biochem 37:1970-1974

Cooper R. 1959. Bacterial fertilizers in the
Soviet Union. Soils Fertilizers;22:327-30. De Freitas JR, Banerjee MR, Germida JJ. 1997. Phosphate-solubilizing rhizobacteria enhance the growth and yield but not phosphorus uptake of canola (Brassica napus L.). Biol Fertil Soils 24:358-364

Fraga R, Rodriguez H, Gonzalez T. 2001. Transfer of the gene encoding the NapA acid phosphatase from Morganella morganii to a Burkholderia cepacia strain. Acta Biotechnol 21:359-369

Gaur AC, Ostwal KP. Influence of phosphate dissolving Bacilli on yield and phosphate uptake of wheat crop. Indian J Exp Biol 1972;10:393-4.

Gaur, A. C. and S. Gaind, 1999. Phosphate solubilizing microorganisms-An overview. Agromicrobes. Current trends in life sciences, Today and tomorrows publishers, New Delhi. India. 23:151-164.

Gerretsen FC. 1948. The influence of microorganisms on the phosphate intake by the plant. Plant Soil:1:51-81

Goldstein AH, Liu ST. 1987. Molecular cloning and regulation of a mineral phosphate solubilizing gene from Erwinia herbicola. Biotechnology 5:72-74

Gyaneshwar P, Kumar GN, Parekh LJ, Poole PS. 2002. The role of soil microorganisms in improving $\mathrm{P}$ nutrition of plants. Plant Soil;245:83-93.

Hinsinger P. 2001. Bioavailability of soil inorganic $\mathrm{P}$ in the rhizosphere as affected by root-induced chemical changes: a review. Plant Soil. 237: $173-195$.

Hinsinger P. 2001. Bioavailability of trace elements as related to root-induced chemical changes in the rhizosphere. In: trace elements in the rhizosphere. Eds. GR Gobran, WW Wenzel, E lombi. CRC press: Boca Raton, Fl, USA;.

Khan AA, Jilani G, Akhtar MS, Naqvi SMS, Rasheed M. 2009. Phosphorus solubilizing bacteria: occurrence, mechanisms and their role in crop production. J Agric Biol Sci 1(1):48-58

Khan M, Zaidi SA, Ahmad E. 2014. Mechanism of phosphate solubilization and physiological functions of phosphate- 
solubilizing microorganisms. In: MS Khan. Eds. springer publishers Switzerland; Doi10.1007/978-3-31908216-5 2.

Khan, M. S., A. Zaidi and P. A. Wani. 2007. Role of phosphate-solubilizing microorganisms in sustainable agriculture - A review. Agron. Sustain. Dev. 27:2943.

Kim KY, McDonald GA, Jordan D. 1997. Solubilization of hydroxyapatite by Enterobacter agglomerans and cloned Escherichia coli in culture medium. Biol Fertil Soils 24:347-352

Kloepper JW, Lifshitz K, Schroth MN. 1988. Pseudomonas inoculants to benefit plant production. ISI Atlas Sci Anim Plant Sci. pp. 60-4.

Kucey RMN. 1983. Phosphate solubilizing bacteria and fungi in various cultivated and virgin Alberta soils. Can J Soil Sci 63:671-678

Kumar V, Behl RK, Narula N. 2001. Establishment of phosphate- solubilizing strains of Azotobacter chroococcum in the rhizosphere and their effect on wheat cultivars under greenhouse conditions. Microbiol Res 156:87-93

Leisinger K.M. 1999. Biotechnology and food security, Curr. Sci. India76, 488-500.

Lifshitz R, Kloepper JW, Kozlowski M, Simonson C, Carlson J, Tipping EM, Zalesca I. 1987. Growth promotion of canola (rapeseed) seedlings by a strain of Psedomonas putida under gnotobiotic conditions. Can J Micro- biol;33:390-5.

Maliha R, Samina K, Najma A, Sadia A, Farooq L. 2004. Organic acids production and phosphate solubilization by phosphate solubilizing microorganisms under in vitro conditions. Pak J Biol Sci 7:187196

McGill WB, Cole CV.1981.Comparative aspects of cycling of organic $\mathrm{C}, \mathrm{N}, \mathrm{S}$ and $\mathrm{P}$ through soil organic matter. Geoderma 26:267-268

Ozanne P.G. 1980. Phosphate nutrition of plants - general treatise. The role of phosphorus in agriculture, in: Khasawneh F.E., sample E.C., Kamprath E.J. (Eds.), American Soc. Agron. Crop Sci. Soc. America,Soil Sci. Soc. America, Madison, WI, USA, pp. 559-589.

Pradel E, Boquet PL. 1990. Nucleotide sequence and transcriptional analysis of the Escherichia coli agp gene en- coding periplasmic acid glucose-1-phosphatase. J Bacteriol;172:802-7.

Ray J, Bagyaraj DJ, Manjunath A. 1981. Influence of soil inoculation with versicular arbuscular mycorrhizal (VAM) and a phosphate dissolving bacteria on plant growth and 32P uptake. Soil Biol Biochem;13:105-8.

Richardson AE. 1994. Soil microorganisms and phosphorus availability. In: Soil Biota, Management in Sustainable Farming Systems. Pankhurst CE, Doube BM, Grupta V VSR, Grace PR. eds. CSIRO, Melbourne, Australia; p. 50-62.

Rodriguez H, Fraga R, Gonzalez T, Bashan Y. 2006. Genetics of phosphate solubilization and its potential applications for improving plant growthpromoting bacteria. Plant Soil 287:15-21

Rossolini GM, Shippa S, Riccio ML, Berlutti F, Macaskie LE, Thaller MC. 1998. Bacterial nonspecific acid phos- phatases: physiology, evolution, and use as tools in microbial biotechnology. Cell Mol Life Sci;54:833-50.

Rudolph W. 1922. Influence of S oxidation upon growth of soybeans and its effect on bacterial flora of soil. Soil Sci 14:247-263

Sperber JI. 1958a. The incidence of apatitesolubilizing organisms in the rhizosphere and soil. Aust J Agr Res 9:778-781

Subba Rao NS. 1982. Advances in agricultural microbiology. In: Subba Rao NS, editor. Studies in the Agricul- tural and Food Sciences. London: Butterworth Scientific. pp. 295-303.

Swaby R, Sperber JI. 1958. Phosphate Dissolving Microorganisms in the Rhizosphere of Legume, Nutrition Of Legumes; Proc. Univ. Nottingham $5^{\text {Th }}$ Easter Sch. Agril. Sci. (CSIRO Adelaide). Soils \& Fert 22, 286(1959):289-294 
Tarafdar J C and Claassen N. 1988. Organic phosphorus compounds as a phosphorus source for higher plants through the activity of phosphatases produced by plant roots and microorganisms. Biol. Fertil. Soils 5, 308-312.

Tarafdar J C and Jung A. 1987. Phosphatase activity in the rhizosphere and its relation to the depletion of soil organic phosphorus. Biol. Fertil. Soils 3, 199204.

Thaller MC, Berlutti F, Schippa S, Lombardi G, Rossolini GM. 1994. Characterization and sequence of PhoC, the principal phosphate-irrepressible acid phosphatase of Morganella morganii. Microbiology; 140:1341-50

Thaller MC, Giovanna L, Serena S, Rossolini GM. 1995a. Cloning and characterization of the NapA acid phos-phatase phosphotransferase of Morganella morganii: Identification of a new family of bacterial acid-phos-phatase-encoding genes. Microbiology;141:147-54.

Thaller MC, Schippa S, Bonci A, Cresti S, Rossolini GM. 1997. Identification of the gene (aphA) encoding the class B acid phosphatase/phosphotransferase of Escherichia coli MG 1655 and characterization of its product. FEMS Microbiol Lett;146:191-8.

Vasil I.K. 1998. Biotechnology and Food security for 21st century: Areal world perspective, Nat. Biotechnol. 16, 399400.

Venkateswarlu B, Rao AV, Raina P, Ahmad N. 1984.Evaluation of phosphorus solubilization by microorganisms isolated from arid soil. J Indian Soc Soil Sci
32:273-277

Wani PA, Zaidi A, Khan AA, Khan MS. 2005. Effect of phorate on phosphate solubilization and indole acetic acid (IAA) releasing potentials of rhizospheric microorganisms. Annals Plant Protection Sci 13:139-144

Whitelaw MA. 2000. Growth promotion of plants inoculated with phosphate solubilizing fungi. Adv Agron 69:99-151

Williamson LC, Ribrioux SPCP, Fitter AH, Leyser HMO. 2001. Phosphate availability regulates root system architecture in arabidopsis. Plant Physiol; 126:875-82.

Wu H. 2005. Identification and characterization of a novel biotin synthesis gene in Saccharomyces cerevisiae. Appl Environ Microbial;71 Suppl 11:6845-55.

Yi Y, Huang W, Ge Y. 2008. Exopolysaccharide: a novel important factor in the microbial dissolution of tricalcium phosphate. World J Microbiol Biotechnol 24:1059-1065

Zaidi A, Khan MS, Ahemad M, Oves M, Wani PA. 2009. Recent Advances in Plant Growth Promotion by PhosphateSolubilizing Microbes. In: Khan MS et al (eds) Microbial Strategies for Crop Improvement. Springer-Verlag, Berlin Heidelberg, pp 23-50

Zhu F, Qu L, Hong X, Sun X. 2011. Isolation and characterization of a phosphatesolubilizing halophilic bacterium Kushneria sp. YCWA18 from Daqiao Saltern on the coast of Yellow Sea of China. Alternative Med 615032:6

\section{How to cite this article:}

Krishnananda Pralhad Ingle, Dipika Ashokrao Padole. 2017. Phosphate Solubilizing Microbes: An Overview. Int.J.Curr.Microbiol.App.Sci. 6(1): 844-852.

doi: http://dx.doi.org/10.20546/ijcmas.2017.601.099 